
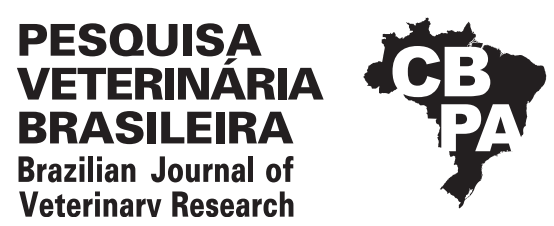

Pesq. Vet. Bras. 40(1):72-76, January 2020 DOI: 10.1590/1678-5150-PVB-6000

Original Article

ISSN 0100-736X (Print) ISSN 1678-5150 (Online)

\title{
Plasma cholinesterase activity as an environmental impact biomarker in juvenile green turtles (Chelonia mydas) $^{1}$
}

\author{
Leandro A. Fonseca ${ }^{2 *}$ (D), Andres M.O. Orozco ${ }^{2}$, Pollyanna C. Souto ${ }^{2}$, \\ Lorraine R.S. Dornelas ${ }^{2}$, Wilson P.C. Filho ${ }^{2}$, Fabricia M. Girardi ${ }^{2}$, \\ Pedro A.N. Ermita ${ }^{3}$ and Valéria Fagundes ${ }^{4}$
}

\begin{abstract}
Fonseca L.A., Orozco A.M.O., Souto P.C., Dornelas L.R.S., Filho W.P.C., Girardi F.M., Ermita P.A.N. \& Fagundes V. 2020. Plasma cholinesterase activity as an environmental impact biomarker in juvenile green turtles (Chelonia mydas). Pesquisa Veterinária Brasileira 40(1):72-76. Departamento de Veterinária, Universidade Federal de Viçosa, Av. Peter Henry Rolfs s/n, Campus Universitário, Viçosa, MG 36570-900, Brazil. E-mail: leandroabreu@ufv.br

The objective of this study was to evaluate the enzymatic activity of plasma cholinesterase in Chelonia mydas marine turtles belonging to two populations, according to their capture sites, under the absence and probable influence of anthropic effects. A total of 74 animals were used and later divided into two groups, based on the capture site. Blood samples were collected from all captured animals, which were then released into the sea at the site of capture. A descriptive statistical analysis of the plasma cholinesterase activity values and an analysis comparing these values based on the capture site were performed. Samples of heparinized plasma from animals captured at the two different sites were analyzed. Plasma cholinesterase activity ranged from 121 to $248 \mathrm{U} / \mathrm{L}$, with a mean and standard deviation of $186.1 \pm 30.68 \mathrm{U} / \mathrm{L}$. When comparing plasma cholinesterase activity values in individuals based on the capture site, a significant difference was observed. Establishing reference values for different sea turtle populations is necessary to interpret future sampling results and to allow sea turtles to be used as sentinels of ecosystem health. Future studies are needed to evaluate other populations and the activity of plasma cholinesterase in juvenile marine turtles, in relation to environmental contamination.
\end{abstract}

INDEX TERMS: Plasma cholinesterase, environmental impact, biomarker, green turtles, Chelonia mydas, cholinesterase, marine turtle, biochemical markers, turtles, wildlife animals.

RESUMO.- [Atividade da colinesterase plasmática como biomarcador de impacto ambiental em tartarugas verdes juvenis (Chelonia mydas).] O objetivo desse estudo foi avaliar a atividade enzimática da colinesterase plasmática em tartarugas marinhas da espécie Chelonia mydas em duas populações de acordo com o local de captura, sob ausência e

\footnotetext{
${ }^{1}$ Received on June 13, 2019.

Accepted for publication on July 29, 2019.

${ }^{2}$ Graduate Program in Veterinary Medicine, Departamento de Veterinária, Universidade Federal de Viçosa (UFV), Av. Peter Henry Rolfs s/n, Campus Universitário, Viçosa, MG 36570-900, Brazil. *Corresponding author: leandroabreu@ufv.br

${ }^{3}$ Universidade Federal do Sul e Sudeste do Pará (Unifesspa), Rua Maranhão s/n, Centro, Xinguara, PA 68555-250, Brazil.

${ }^{4}$ Universidade Federal do Espírito Santo (UFES), Av. Fernando Ferrari 514, Goiabeiras, Vitória, ES 29075-010, Brazil.
}

provável influência de efeito antrópico. Foi utilizado um total de 74 animais e posteriormente divididos em dois grupos de acordo com o local de captura. Foram coletadas amostras de sangue de todos os animais capturados e em seguida liberados ao mar no mesmo local. Foi realizada uma análise estatística descritiva dos valores da atividade plasmática de colinesterase do total de animais e análise comparando os valores de acordo com o local de captura. Foram analisadas amostras de plasma heparinizado de animais capturados em dois locais distintos. Os valores da atividade plasmática de colinesterase variaram de 121 a $248 \mathrm{U} / \mathrm{L}$, com média e desvio padrão de 186.1 $\pm 30.7 \mathrm{U} / \mathrm{L}$. Quando comparados os valores de atividade plasmática da colinesterase nos indivíduos de acordo com o local de captura, foi observada diferença significativa. 0 estabelecimento de valores de referência para diferentes populações de tartarugas marinhas são necessários para 
interpretar os futuros resultados amostrais e permitir que as tartarugas marinhas sejam usadas como sentinelas da saúde do ecossistema. Estudos futuros são necessários para avaliar outras populações e a atividade da colinesterase plasmática de tartarugas marinhas juvenis em relação à contaminação ambiental.

TERMOS DE INDEXAÇÃO: Colinesterase plasmática, biomarcador, impacto ambiental, tartarugas verdes, Chelonia mydas, tartaruga marinha, marcadores bioquímicos, animais selvagens.

\section{INTRODUCTION}

With modernization, industrial and urban development has been expanding, which brings important environmental impacts. In light of this, it is necessary to control the emission of pollutants, since they can compromise water resources, which are of great importance to ecosystems (Freitas 2009). The production of potential synthetic compounds from industrial, agricultural and domestic activities is responsible for much of the contamination of the waters that reach rivers and oceans. Accordingly, a multitude of chemical products in various concentrations (Freire et al. 2008) accumulate in animals living in marine environments (Coito et al. 2007).

Monitoring the aquatic environment is necessary. For this, biomarkers have been used to identify the presence of contaminating agents and their interaction with the organisms (Sarkar et al. 2006) that use these environments, in a predictive manner, thus avoiding the occurrence of irreversible environmental damage (Cajaraville et al. 2000). Some environmental monitoring programs have used the inhibition of acetylcholinesterase enzymatic activity in fish and other animals as a biomarker indicative of environmental contamination by organophosphates and carbamates (Oliveira et al. 2007).

Cholinesterases are enzymes that are responsible for the hydrolysis of choline esters. There are two types of cholinesterases: I) acetylcholinesterase (AChE) or erythrocyte cholinesterase, which is most concentrated in the central nervous system, striated muscle and erythrocyte membrane; and II) butyrylcholinesterase (BChE) or plasma cholinesterase, which is most abundant in plasma (Kramer \& Hoffmann 1997). According to other studies, acetylcholinesterase may also be inhibited by heavy metals and surfactants (Coito et al. 2007).

According to Fonseca et al. (2015),marine turtles of the Chelonia mydas species can be used as sentinels of exposure to pollutants that inhibit the enzymatic activity of plasma cholinesterase, since these animals have detectable activities of this enzyme. However, these authors suggest evaluating the enzymatic activity in this species under different conditions and exposures, both in situ via comparison between sites and ex situ through bioassays.

The objective of this study was to evaluate the enzymatic activity of plasma cholinesterase in marine turtles belonging to the $C$. mydas species; these were in two populations, according to their capture sites, under the absence and probable influence of anthropic effects.

\section{MATERIALS AND METHODS}

Experimental design. A total of 74 animals were used in our study and later divided into two groups based on their capture sites: G1 and G2. All captured animals were banded; biometric data and blood were collected immediately after capture. The animals were then released into the sea at the same site. The animals were manually captured at low tide by fishing, using a hand net, or diving, in strategic locations and monitored by GPS. Licenses for the collection, transport and handling of biological material were granted by the Biodiversity Information and Authorization System (SISBIO)/ICMBio - IBAMA, under registration number 26080 .

A descriptive statistical analysis of the plasma cholinesterase activity values of the animals and an analysis comparing these values based on the capture sites were performed. The G1 comprised 35 individuals captured in the Bay of Sueste in the Archipelago of Fernando de Noronha, state of Pernambuco (351'26" S and $32^{\circ} 25^{\prime} 33^{\prime \prime} \mathrm{W}$ ), Brazil. The region is characterized as an important feeding and spawning area of Chelonia mydas (Bellini et al. 1996, Baptistotte 2007). Because the animals were in the open sea, the manual capture involved continuous, prolonged chases and required diving and pursuit durations of over 60 minutes until the individuals could be captured and transported to the beach. During this pursuit, the capture was realized when the individuals, worn out by the fugue, rose to the surface to breathe and could not escape the capture. Following the capture, the animals were transported to the beach for blood collection, banding, biometry measurements, and subsequent release.

The G2 comprised 39 individuals captured from the final effluent of a steelworks company in the city of Vitória, state of Espírito Santo $\left(20^{\circ} 15^{\prime} 49^{\prime \prime} \mathrm{S}\right.$ and $\left.40^{\circ} 13^{\prime} 43^{\prime \prime} \mathrm{W}\right)$, Brazil. In this region, seawater is collected and used for cooling in industrial operations, thus causing an increase in the local average temperature of the water, in addition to receiving domestic and industrial sewage after treatment. The high water temperature and the richness of organic matter favor the growth of algae. According to Torezani et al. (2010), these conditions lead to noticeable growth, mainly of green algae Enteromorpha flexuosa, but also of Pterocladiella sp., Jania sp., Arthrocardia sp. and Chaetomorpha sp. Four capture points were previously defined on both sides of the effluent channel. This effluent channel is $500 \mathrm{~m}$ long and approximately $33 \mathrm{~m}$ wide, with an average depth of $2 \mathrm{~m}$.

Table 1. Characteristics of study groups (G1 and G2) of the present study

\begin{tabular}{ccc}
\hline Criteria & G1 & G2 \\
\hline Capture and manipulation time & Average over 60 minutes & Average less than 60 minutes \\
Average water temperature & $28^{\circ} \mathrm{C}^{\mathrm{a}}\left(82.4^{\circ} \mathrm{F}\right)$ & $22^{\circ} \mathrm{C}\left(71.6^{\circ} \mathrm{F}\right)$, increased by $8.75^{\circ} \mathrm{C}^{\mathrm{b}}\left(47.8^{\circ} \mathrm{F}\right)$ \\
Capture method & Diving with continuous pursuit & Fishing hand net \\
Number of animals & 35 & 39 \\
Site & Fernando de Noronha/PE & Vitória/ES
\end{tabular}


As the animals were aggregated in the effluent channel, and by the use of fishing hand nets, the process involved surprising the animals without persecution (Table 1).

The areas used in our study were chosen and characterized using the information described by Dos Santos et al. (2010), who evaluated the environmental quality of both localities using the ecological evaluation index (EEI) (Orfanidis et al. 2001, 2003) and concluded that the area used in our study to capture individuals from G1 was classified as of good quality, in contrast to the area used to capture individuals from G2 that was characterized as of bad quality.

Collection of blood and biometric data. From all the captured individuals, carapace size data (in centimeters); curvilinear carapace length (CCL) and weight (in grams) were obtained to characterize the age of the animal, and blood was collected. Recaptured animals were evaluated, measured, weighed, and released without further blood collection. The sex of the animals was not determined due to the absence of external sexual dimorphism at this stage of the life cycle. Peripheral blood collection was performed by venipuncture of the cervical sinus or jugular vein, preceded by adequate cleaning and antisepsis with iodinated alcohol. Blood was immediately transferred to a $2 \mathrm{ml}$ heparin-containing tube (Vacutainer ${ }^{\circledR}$ ) and was kept cool in an ice container until arrival at the laboratory.

Sample processing. In the laboratory, heparin tube-conditioned blood was centrifuged for 10 minutes at $4000 \mathrm{rpm}$, and the obtained plasma was transferred to $1.7 \mathrm{ml}$ microtubes for cholinesterase dosing. Heparinized plasma was frozen at $-20^{\circ} \mathrm{C}\left(68^{\circ} \mathrm{F}\right)$ until the samples were processed. To measure the cholinesterase enzyme activity, we followed the method of Ellman et al. (1961), modified by Sturm et al. (1999), which allows for the quantification of enzyme activity in plasma samples (Fonseca et al. 2015). The determination of cholinesterase plasma activity was performed using the kinetic enzymatic method. The reaction occurs due to the catalytic action of cholinesterase on the hydrolysis of butyrylthiocholine to thiocoline and butyrate. Thus, thiocholine reduces hexacyanoferrate III (which is yellow in color) to hexacyanoferrate II (colorless). The decrease in absorbance was measured at $405 \mathrm{~nm}$ and represents the intensity of the enzymatic activity. For this dosage, the test had a minimum detection limit of $50 \mathrm{U} / \mathrm{L}$ and the reaction was linear up to $25000 \mathrm{U} / \mathrm{L}$.

Statistical analysis. The results were submitted to descriptive analysis to obtain means and standard deviations. The symmetry of the data distribution was evaluated using a Shapiro-Wilk test, and the homogeneity of the variances was evaluated using a Levene's test. For the determination of the reference range, the outliers were detected and discarded, according to the Tukey procedure, where a result is defined as extreme when its value is less than the first quartile minus 1.5 times the interquartile range, or greater than the third highest quartile plus 1.5 times the interquartile range, similar to that used by Friedberg et al. (2007). After the outliers were removed, the $95 \%$ confidence interval was obtained. The procedure was performed using SPSS 20 software (IBM SPSS Statistics). The influence of the capture site on plasma cholinesterase levels was assessed using a Student's t-test for independent samples. The statistical package Minitab 17 (Minitab Inc.) was used and significance was considered when $\mathrm{p}<0.05$.

\section{RESULTS}

All captured animals were juveniles, according to the criteria proposed by Hirth (1971), i.e., curvilinear carapace length (CCL) was less than $73.5 \mathrm{~cm}$. The animals presented CCLs ranging from 28.4 to $56.3 \mathrm{~cm}$, with a mean and standard deviation of $51.8 \pm 11.3 \mathrm{~cm}$.

Heparinized plasma samples from the 74 animals captured from two different sites were analyzed. All analyzed samples showed some enzymatic activity of plasma cholinesterase. Plasma cholinesterase activity ranged from 121 to $258 \mathrm{U} / \mathrm{L}$, with a mean and standard deviation of $186.1 \pm 30.7 \mathrm{U} / \mathrm{L}$. The results of the descriptive statistical analysis of plasma cholinesterase activity are presented in Table 2 and a graphical representation is presented in Figure 1. When comparing plasma cholinesterase activity values between individuals according to the capture site, a significant difference was observed.

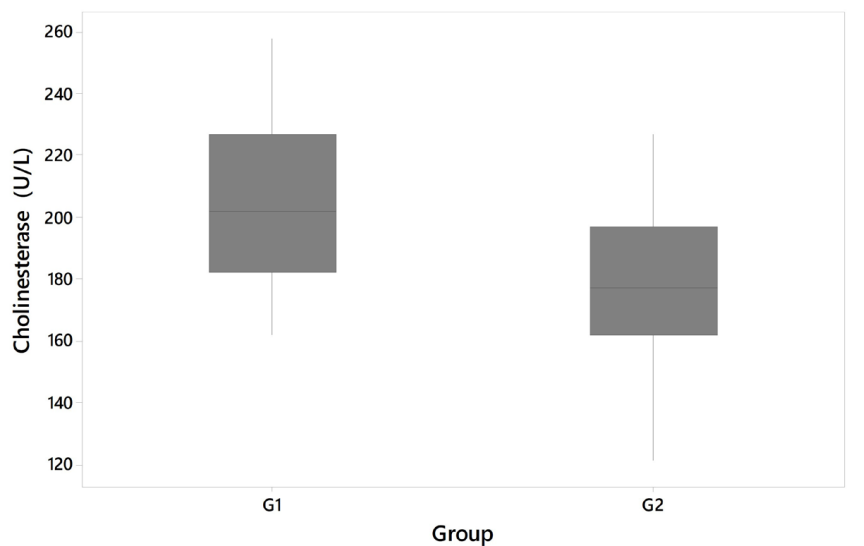

Fig.1. Graphical representation for cholinesterase activity (U/L) in green turtle (Chelonia mydas) from Brazil.

Table 2. Descriptive statistics for cholinesterase activity (U/L) in green turtle (Chelonia mydas) from Brazil

\begin{tabular}{|c|c|c|c|}
\hline \multirow{2}{*}{ Statistic } & \multicolumn{3}{|c|}{ Plasma cholinesteraseactivity (U/L) } \\
\hline & Total & Group 1 & Group 2 \\
\hline Number of samples & 74 & 35 & 39 \\
\hline Mean + SD & $186.1+30.7$ & $178.2 \pm 26.9^{a}$ & $194.1 \pm 32.5^{b}$ \\
\hline 95\% Lower confidence interval & 178.8 & 200.1 & 170.3 \\
\hline 95\% Upper confidence interval & 193.4 & 232.7 & 186.7 \\
\hline Minimum & 121 & 162 & 121 \\
\hline Maximum & 258 & 258 & 227 \\
\hline
\end{tabular}

SD = Standard deviation; ${ }^{\mathrm{a}, \mathrm{b}}$ Different letters on the same line demonstrate significant statistical difference. 


\section{DISCUSSION}

In veterinary medicine, the determination of reference biochemical values is indispensable for the monitoring of the health status of individuals of different species. Some of these parameters can be used as biomarkers, and according to Atkinson Junior et al. (2001), their measurement serves as an indicator of a normal biological process, pathogenic, or in response to a therapeutic intervention. In this study, the method used to measure cholinesterase activity was the same as that used by Fonseca et al. (2015) and all animals in the study had some type of activity for this enzyme.

As the animals in the G1 were captured in an environmental conservation unit and did not present any evidence that could directly or indirectly interfere with plasma cholinesterase activity, the data obtained in our study can be proposed as a reference for this site for future studies of Chelonia mydas juveniles, as there is no data in the current literature for the studied species and age group.

Animals are often exposed to toxins of various origins. The evaluation of biomarkers permits the evaluation of an individual's exposure to these substances and their health effects on the body (Myers et al. 2017). The difference in the values found between the groups in our study demonstrates that the activity of this enzyme can vary according to the environmental conditions in which the animals live.

Cholinesterase activity has been used as an indicator of environmental contamination in several species and situations. In dogs, the inhibition of cholinesterase activity is an indicator of exposure to organophosphorus toxins (Ferré et al. 2015) and carbamates (Saldeña et al. 2017). In birds, studies have evaluated the activity of this enzyme. In northeast Mexico, cholinesterase activity decreased by $29-49 \%$ because of possible exposure to pestivcides (Ruvalcaba-Ortega et al. 2017). In Spain, Oropesa et al. (2017) observed a decrease in plasma cholinesterase activity under in vitro conditions in samples of griffon vultures (Gyps fulvus) exposed to carbamates, suggesting that it is a suitable biomarker for monitoring the exposure of this toxin.

Similarly, in aquatic environments, the enzymatic activity of cholinesterase has been studied as an indication of environmental contamination (Oliveira et al. 2007). Accordingly, some aquatic species can be considered sentinels. According to the results obtained by Coito et al. (2007), marine sponges belonging to the species Spongia officinalis and Spongia agaricina show cholinesterase activity and can be used as biomarkers of pesticide exposure. Omar-Ali et al. (2017) found a significant decrease in plasma acetylcholinesterase activity in Atractosteus spatula (alligator gar) under chronic exposure to organophosphate pesticide (diazinon). However, in our study, no evidence of environmental contamination by pesticides was measured.

However, plasma cholinesterase activity may vary as a function of exposure to other toxic compounds, depending on the exposure period. When studying the effect of exposure to iron on acetylcholinesterase (AChE) enzyme activity in fish brains and livers, Sant'Anna et al. (2011) observed an increase of this enzyme 24 hours after exposure. Carvalho et al. (2017) obtained similar results when they evaluated the activity of this enzyme in the brain of tadpoles after 48 hours of exposure to different types of heavy metals. However, after 16 days, a significant decrease of the enzymatic activity was demonstrated, which suggests that $\mathrm{AChE}$ can be used as a predictive biomarker in heavy metal-contaminated environments.
Environmental contamination by iron ore is an old, widely-discussed problem in the locality in which the G2 resides (Pinheiro 2013). In addition, as already mentioned, the locality of G2 also has an elevated water temperature and the presence of abundant organic matter of algae. In our study, animals from the G2 showed an increase in enzymatic activity, when compared to those of the G1. This difference may suggest an anthropogenic influence on the habitat in which the G2 inhabited. Thus, among some possibilities, it can be assumed that environmental contamination by iron ore, a problem experienced for years by the local population (Nassar et al. 2003), is a possible cause of the elevation of enzymatic activity. However, although analyses of the composition of the local water are carried out periodically, the results were not available in full. Further studies on the composition of the heavy metals present in this water and the time the animals are exposed to the toxics present in the effluent need to be performed.

Das (2007) and Silva et al. (2012) report that acetylcholinesterase and butyrylcholinesterase can be considered biomarkers of low-grade inflammation in various clinical conditions. This is because acetylcholinesterase and butyrylcholinesterase reduce the levels of acetylcholine, a molecule that plays an anti-inflammatory role locally and systemically by inhibiting the production of tumor necrosis factor, interleukin-1, inhibitory macrophage migration factor, and other proinflammatory cytokines. Thus, with increasing levels of acetylcholinesterase and butyrylcholinesterase, there is an increase in inflammatory events in the body.

Finally, according to Fonseca et al. (2015), because of the longevity of $C$. mydas sea turtles and their herbivorous feeding behavior, together with the fact that they have detectable plasma cholinesterase activity, this species can be proposed as a bioindicator of exposure to pollutants that influence the activity of this enzyme, especially in environments influenced by industrial activities. For this, it is necessary to evaluate enzymatic activity under different conditions and exposures, both in situ by comparison between sites and ex situ through bioassays. The possibility of using blood samples permits the development of studies that use minimally invasive techniques and minimize the ethical considerations of animal use in research.

\section{CONCLUSIONS}

In the present study, significant differences in plasma cholinesterase activity were observed among the evaluated populations.

Group 2 turtles showed higher activity of AChE in relation to Group 1 ; this could be attributed to an altered state caused by the anthropic effect on the habitat of these animals.

Establishing reference values for different sea turtle populations is necessary to interpret future sampling results and allows sea turtles to be used as sentinels of ecosystem health.

Future studies are necessary to evaluate other populations and the effect of different toxins on plasma cholinesterase activity in juvenile sea turtles.

Acknowledgments.- We thank the "Fundação de Amparo à Pesquisa e Inovação do Espírito Santo" (FAPES), the "Fundação de Amparo a Pesquisa do Estado de Minas Gerais" (FAPEMIG) and the "Conselho Nacional de Desenvolvimento Científico e Tecnológico" (CNPq) for their support.

Conflict of interest statement.- The authors have no competing interests. 


\section{REFERENCES}

Atkinson Junior A.J., Colburn W.A., DeGruttola V.G., DeMets D.L., Downing G.J., Hoth D.F., Oates J.A., Peck C.C., Schooley R.T. \& Spilker B.A. 2001. Biomarkers and surrogate endpoints: preferred definitions and conceptual framework. Clin. Pharmacol. Ther. 69(3):89-95.<http://dx.doi.org/10.1067/ mcp.2001.113989><PMid:11240971>

Baptistotte C. 2007. Caracterização espacial e temporal da fibropapilomatose em tartarugas marinhas da costa brasileira. Doctoral Dissertation, Universidade de São Paulo, São Paulo. 66p.

Bellini C., Marcovaldi M.A., Sanches T.M., Grossman A. \& Sales G. 1996. Atol das Rocas biological reserve: second largest Chelonia rookery in Brazil. Mar. Turt. Newsl. 72:1-2.

Cajaraville M.P., Bebianno M.J., Blasco J., Porte C., Sarasquete C. \& Viarengo A. 2000. The use of biomarkers to assess the impact of pollution in coastal environments of the Iberian Peninsula: a practical approach. Sci. Total Environ. 247(2):295-311. <http://dx.doi.org/10.1016/S0048-9697(99)00499-4> $<$ PMid:10803557>

Carvalho C.S., Utsunomiya H.S., Pasquoto T., Costa M.J. \& Fernandes M.N. 2017. Cholinesterase activity aspotential biomarkers: Characterization in bullfrog tadpole's brain after exposure to metals. XVII Safety, Health and Environment World Congress, Vila Real, Portugal, p.86-88. (Resumo)

Coito R., Torres P., Costa M., Humanes M. \& Almeida M. 2007. Actividade de acetilcolinesterase em esponjas marinhas da costa portuguesa. Revta Lusóf. Ciênc. Tecnol. Saúde. 4(2):202-214.

Das U.N. 2007. Acetylcholinesterase and butyrylcholinesterase as possible markers of low-grade systemic inflammation. Med. Sci. Monit. 13(12):RA214RA221. <PMid:18049445>

Ellman G.L., Courtney K.D., Andres Júnior V. \& Featherstone R.M. 1961. A new and rapid colorimetric determination of acetylcholinesterase activity. Biochem. Pharmacol. 7(2):88-95. <http://dx.doi.org/10.1016/00062952(61)90145-9> <PMid:13726518>

Ferré D.M., Saldeña E.L., Albarracín L., Neuilly V. \& Gorla N.B. 2015. Inhibición de butirilcolinesterasa en dos perros intoxicados y confirmación analítica de carbofuran como agente causal. Revta Vet. 26(1):43-48.

Fonseca L.A., Fagundes V., Girardi F.M., Maia N.L., Pimentel F.G., Braga F.R., Hiura E. \& Santos M.R. 2015. Atividade da colinesterase plasmática como biomarcador de impacto ambiental em tartarugas verdes (Chelonia mydas) no litoral do Arquipélago de Fernando de Noronha, Pernambuco. Pesq. Vet. Bras. 35(4):385-389. <http://dx.doi.org/10.1590/S0100736X2015000400012>

Freire M.M., Santos V.G., Ginuino I.S.F. \& Arias A.R.L. 2008. Biomarcadores na avaliação da saúde ambiental dos ecossistemas aquáticos. Oecologia Australis 12(3):347-354. <http://dx.doi.org/10.4257/oeco.2008.1203.01>

Freitas A.P. 2009. Filogenia da sensibilidade da acetilcolinesterase cerebral de peixe ao metil-paraoxon como um possível marcador ambiental. Master's Thesis, Fundação Oswaldo Cruz, Escola Nacional de Saúde Pública Sergio Arouca, Rio de Janeiro. 49p.

Friedberg R.C., Souers R., Wagar E.A., Stankovic A.K. \& Valenstein P.N. 2007. The origin of reference intervals: a College of American Pathologists Q-Probes study of "normal ranges" used in 163 clinical laboratories. Arch. Pathol. Lab. Med. 131(3):348-357. <PMid:17516737>

Hirth H. 1971. Synopsis of biological data on the green turtle, Chelonia mydas (Linnaeus) 1758. FAO Fisheries Synopsis no. 85. Food and Agriculture Oganization of the United Nations, Rome. 84p.

Kramer J.W. \& Hoffmann W.E. 1997. Clinical enzymology, p.303-325. In: Kaneko J.J., Harvey J.W. \& Bruss M.L. (Eds), Clinical biochemistry of domestic animals. 5th ed. Elsevier, San Diego. <http://dx.doi.org/10.1016/B978012396305-5/50013-0>.

Mendes L.F. 2006. História natural dos amborés e peixes-macaco (Actinopterygii, Blennioidei, Gobioidei) do Parque Nacional Marinho do Arquipélago de Fernando de Noronha, sob um enfoque comportamental. Revta Bras. Zool. 23(3):817-823. http://dx.doi.org/10.1590/S0101-81752006000300029.
Myers M.J., Smith E.R. \& Turfle P.G. 2017. Biomarkers in veterinary medicine. Ann. Rev. Animal Biosci. 5(1):65-87. <http://dx.doi.org/10.1146/annurevanimal-021815-111431><PMid:27860493>

Nassar C.A.G., Salgado L.T., Yoneshigue-Valentin Y. \& Amado-Filho G.M. 2003. The effect of iron-ore particles on the metal content of the brown alga Padina gymnospora (Espírito Santo Bay, Brazil). Environ. Pollut. 123(2):301-305. <http://dx.doi.org/10.1016/S0269-7491(02)00369-X><PMid:12628209>

Oliveira M.M., Silva Filho M.V., Cunha Bastos V.L., Fernandes F.C. \& Cunha Bastos J.. 2007. Brain acetylcholinesterase as a marine pesticide biomarker using Brazilian fishes. Mar. Environ. Res. 63(4):303-312. <http://dx.doi. org/10.1016/j.marenvres.2006.10.002 > <PMid:17118441>

Omar-Ali A., Carr R.L. \& Petrie-Hanson L. 2017. Inhibition of plasma cholinesterase activity in Alligator Gar (Atractosteus spatula) following chronic exposure to diazinon. J. Toxicol. Pharmacol. 1(3)10:14.

Orfanidis S., Panayotidis P. \& Stamatis N. 2001. Ecological evaluation of transitional and coastal waters: a marine benthic macrophytes-based model. Medit. Mar. Sci. 2(2):45-65. <http://dx.doi.org/10.12681/mms.266>

Orfanidis S., Panayotidis P. \& Stamatis N. 2003. An insight to ecological evaluation index (EEI). Ecol. Indic. 3(1):27-33. <http://dx.doi.org/10.1016/ S1470-160X(03)00008-6>

Oropesa A.L., Sánchez S. \& Soler F. 2017. Characterization of plasma cholinesterase activity in the Eurasian Griffon Vulture (Gyps fulvus) and its in vitro inhibition by carbamate pesticides. Ibis. 159(3):510-518. <http:// dx.doi.org/10.1111/ibi.12476>

Pinheiro L.F.M.A. 2013. A construção de um problema social: a poluição do ar e as audiências públicas. Revta Direito Amb. Soc. 3(1):261-287.

Ruvalcaba-Ortega I., León M.B.D., Mendiola-Castillo S., González-Escalante L., Canales-del-Castillo R., Mercado-Hernández R., Guzmán-Velasco A. \& González-Rojas J.I. 2017. Evaluation of plasma cholinesterase activity in native birds from pesticide-exposed agricultural lands. Rangel. Ecol. Manag. 70(5):584-588. <http://dx.doi.org/10.1016/j.rama.2017.03.003>

Saldeña E.L., Hynes V., Ferré D.M., Quero M., Neuilly V. \& Gorla N. 2017. Evento de intoxicación en perros de zona urbana mediante cebos contaminados con aldicarb. Revta Investig. Vet. Perú 28(3):514-521.

Sant'Anna M.C., Soares Vde.M., Seibt K.J., Ghisleni G., Rico E.P., Rosemberg D.B., Oliveira J.R., Schröder N., Bonan C.D. \& Bogo M.R.. 2011. Iron exposure modifies acetylcholinesterase activity in zebrafish (Danio rerio) tissues: distinct susceptibility of tissues to iron overload. Fish Physiol. Biochem. 37(3):573-581. <http://dx.doi.org/10.1007/s10695-010-9459-7> $<$ PMid:21194010>

Santos R.G., Martins A.S., Torezani E., Baptistotte C., Nóbrega F.J., Horta P.A., Work T.M. \& Balazs G.H. 2010. Relationship between fibropapillomatosis and environmental quality: a case study with Chelonia mydas off Brazil. Dis. Aquat. Organ. 89(1):87-95. <http://dx.doi.org/10.3354/dao02178> <PMid:20391916>

Sarkar A., Ray D., Shrivastava A.N. \& Sarker S. 2006. Molecular biomarkers: Their significance and application in marine pollution monitoring. Ecotoxicology 15(4):333-340. <http://dx.doi.org/10.1007/s10646-0060069-1><PMid:16676218>

Silva C.B., Wolker P., Silva A.S., Paim F.C., Tonin A.A., Castro V.S.P., Felin D.V., Schmatz R., Gonçalves J.F., Badke M.R.T., Morsch V.M., Mazzanti C.M. \& Lopes S.T.A. 2012. Cholinesterases as markers of the inflammatory process in rats infected with Leptospira interrogans serovar Icterohaemorrhagiae. J. Med. Microbiol. 61(2):278-284.<http://dx.doi.org/10.1099/jmm.0.035501-0> <PMid:21921108>

Sturm A., da Silva de Assis H.C. \& Hansen P.D. 1999. Cholinesterases of marine teleost fish: enzymological characterization and potential use in the monitoring of neurotoxic contamination. Mar. Environ. Res. 47(4):389398. <http://dx.doi.org/10.1016/S0141-1136(98)00127-5>

Torezani E., Baptistotte C., Mendes S.L. \& Barata P.C.R. 2010. Juvenile green turtles (Chelonia mydas) in the effluent discharge channel of a steel plant, Espírito Santo, Brazil, 2000-2006. J. Mar. Biol. Assoc. 90(2):233-246. <http://dx.doi.org/10.1017/S0025315409990579> 